УДК 642.58:796.071.2

Ю.М. МОТУЗКА

Київський національний торговельно-економічний університет

\title{
ІДЕНТИФІКАЦІЯ ХАРЧОВИХ ПРОДУКТІВ ДЛЯ СПОРТСМЕНІВ
}

Ю.Н. МОТУЗКА

Киевский национальный торгово-экономический университет

\section{ИДЕНТИФІКАЦИЯ ПИЩЕВЫХ ПРОДУКТОВ ДЛЯ СПОРТСМЕНОВ}

I. MOTUZKA

Kyiv National University of Trade and Economics

\section{IDENTIFICATION OF FOOD PRODUCTS FOR SPORTSMEN}

\section{https://doi.org/10.36910/6775-2310-5283-2020-13-03}

Мета. Розробка науково-практичних підходів до ідентифікації харчових продуктів для спортсменів.

Методика. В основу методологічної бази дослідження покладено методи наукового пізнання, системного підходу та узагальнення, законодавчо-нормативні акти України та ЄC, наукові праці.

Результати. Постійне зростання на вітчизняному ринку кількості фальсифікованих харчових продуктів для спортсменів, їх незаконне переміщення через митний кордон та інші чинники зумовлюють необхідність проведення робіт з ідентифікаиії. Нормативна база щзодо виробництва та обігу харчових продуктів для спортсменів не визначає чіткої регламентації проведення процедури їх ідентифікації, тому важливим вбачається розробка та впровадження дієвого механізму контролю достовірності тверджень виробників щуодо особливих властивостей харчових продуктів, що базуватиметься на науковому підході та з використанням новітніх методів ідентифікації. Встановлено, щуо для проведення ідентифікаційної експертизи харчових продуктів для спортсменів важсливим етапом $\epsilon$ розробка критеріїв та засобів ідентифікаиії.

В роботі розроблено критерії ідентифікачії харчових продуктів для спортсменів на прикладі батончиків. До важливих критеріїв ідентифікаиї даної групи продуктів належать: маркування, смак, запах, зовнішній вигляд, форма, иукеркова маса, маса нетто, масова частка вологи і масова частка вуглеводів, походження білкової та жирової складових; кількісний та якісний склад біологічно-активних речовин.

За результатами ідентифікації за органолептичними та фізико-хімічними показниками досліджувані зразки батончиків для спортсменів відповідають вимогам 
діючого нормативного документу. Однак, використання лише стандартизованих показників якості з метою ідентифікачії не забезпечує об'єктивне проведення прочедури ідентифікації продуктів. Дочільним вбачається включення розроблених критеріїв ідентифікації до нормативного документа, оскільки, саме ие дасть можливість об'єктивно провести експертизу товару. Подальшого дослідження потребує розробка засобів ідентифікаиії складу продуктів для спортсменів із використанням експресметодик та проведення стандартизації запропонованих критеріїв ідентифікації.

Наукова новизна. Проаналізовано підходи до ідентифікації харчових продуктів для спортсменів. Розроблено критерії ідентифікації батончиків для спортсменів.

Практична цінність. Запропоновано стандартизувати розроблені критерії ідентифікації шляхом їх включення до нормативної документації для ефективності проведення проиедури ідентифікаиії контролюючими органами, торговельними організачіями, споживачами.

Ключові слова: харчові продукти для спортсменів, ідентифікація, критерій ідентифікачіï, засіб ідентифікачії, ринок, регламент.

\section{Постановка проблеми у загальному вигляді та її зв'язок з важливими} науковими та практичними завданнями. Харчові продукти, що використовуються для харчування спортсменів представляють собою групу продуктів заданої харчової, енергетичної цінності та направленої ефективності, що складаються 3 набору нутрієнтів, які мають специфічний вплив на підвищення адаптивних можливостей організму людини до фізичних і нервово-емоційних навантажень, сприяючи досягненню високих результатів. Необхідність постійно підвищувати ефективність тренувального процесу, популяризація тренду здорового харчування серед населення сприяють появі нових виробників на ринку продуктів спортивного харчування та розширенню асортименту продуктів та стимулюють проведення широкомасштабних досліджень в цій галузі [1]. Постійне зростання на вітчизняному ринку кількості фальсифікованих харчових продуктів для спортсменів, їх незаконне переміщення через митний кордон та інші причини зумовлюють практичну необхідність проведення робіт з ідентифікації. Масштаби їх проведення вкрай обмежені. Зокрема, ідентифікація фактично запроваджена в практику митних органів і установ системи захисту прав споживачів; без неї неможливе проведення жодної товарознавчої експертизи та встановлення відповідності товарів певним позиціям УКТЗЕД.

Основними причинами фальсифікації харчових продуктів для спортсменів в Україні $є$ : недосконалість нормативно-правової бази, відсутність чіткого механізму проведення процедури ідентифікації та 
відсутність належних матеріально-технічних умов для проведення робіт 3 розробки критеріїв та засобів ідентифікації [2].

Необхідність формування наукових засад ідентифікаційної експертизи харчових продуктів для спортсменів, вдосконалення засобів i методів іiі проведення обумовлена наступними чинниками: наявністю на споживчому ринку великої кількості імпортних товарів: зміною складу i технологій виробництва багатьох харчових продуктів; широким розповсюдженням фальсифікованих харчових продуктів для спортсменів тощо.

Аналіз останніх досліджень, у яких започатковано вирішення проблеми. Значний внесок у розробку теоретико-практичних засад ідентифікації харчових продуктів зробили вчені Ніколаєва М.А., Притульська H.B., Дубініна A.A., Rahmatia Sh., Bottero T. та ін. [2-6]. Але наукові праці були зосереджені переважно на створенні теоретичного підгрунтя процедури ідентифікації та аналізі існуючих видів фальсифікації традиційних харчових продуктів. Одним із трендів сучасної світової харчової промисловості є група продуктів, орієнтованих на задоволення потреб певних категорій споживачів (людей 3 підвищеним фізико-емоційним навантаженням, хворих, спортсменів). Враховуючи затребуваність даної групи продуктів у споживачів, постійно зростаючі об'єми виробництва, необхідним є створення теоретикопрактичної бази щодо їх ідентифікації.

Цілі статті. Метою роботи є розробка науково-практичних підходів до ідентифікації харчових продуктів для спортсменів.

Об’єкт дослідження. Об'єктом дослідження є харчові продукти для спортсменів вітчизняного та зарубіжного виробництва. Предметом дослідження $є$ критерії та засоби ідентифікації харчових продуктів для спортсменів.

Методи дослідження. В основу методологічної бази дослідження покладено методи наукового пізнання, системного підходу та узагальнення, законодавчо-нормативні акти України та СС, наукові праці.

Виклад основного матеріалу дослідження 3 повним обгрунтуванням отриманих наукових результатів. Ринок харчових продуктів для спортсменів - один із сегментів світової харчової промисловості, що найбільш успішно розширюється та зростає. Відповідно до результатів маркетингового дослідження Datamonitor, у цілому близько 28\% населення є потенційними споживачами продуктів спортивного харчування, які можуть допомогти їм у досягненні спортивних цілей і покращенні стану здоров'я [7]. Нині на ринку функціонують багато компаній-виробників: «SAN», «Multipower», 
«MuscleTech», «Nutrex», «Optimum Nutrition», «Ironman», «Prolab» та інші. Варто зазначити динамічне зростання попиту на спортивне харчування (гелі, вітамінні концентрати, енергетичні напої та напої для нормалізації водносольового балансу). 3 кожним роком розширюється коло споживачів спортивного харчування, особливо серед спортсменів-аматорів, а це означає, що спортивне харчування більше не використовуються виключно професійними спортсменами або культуристами [8]. Сухі суміші залишаються найбільш популярним форматом спортивного харчування завдяки доступності та низькій ціні. Для їх виробництва традиційно використовують сироватковий або соєвий білок. Водночас, спостерігається чітка тенденція до щорічного збільшення частки батончиків, гелів, напоїв (рис.1).

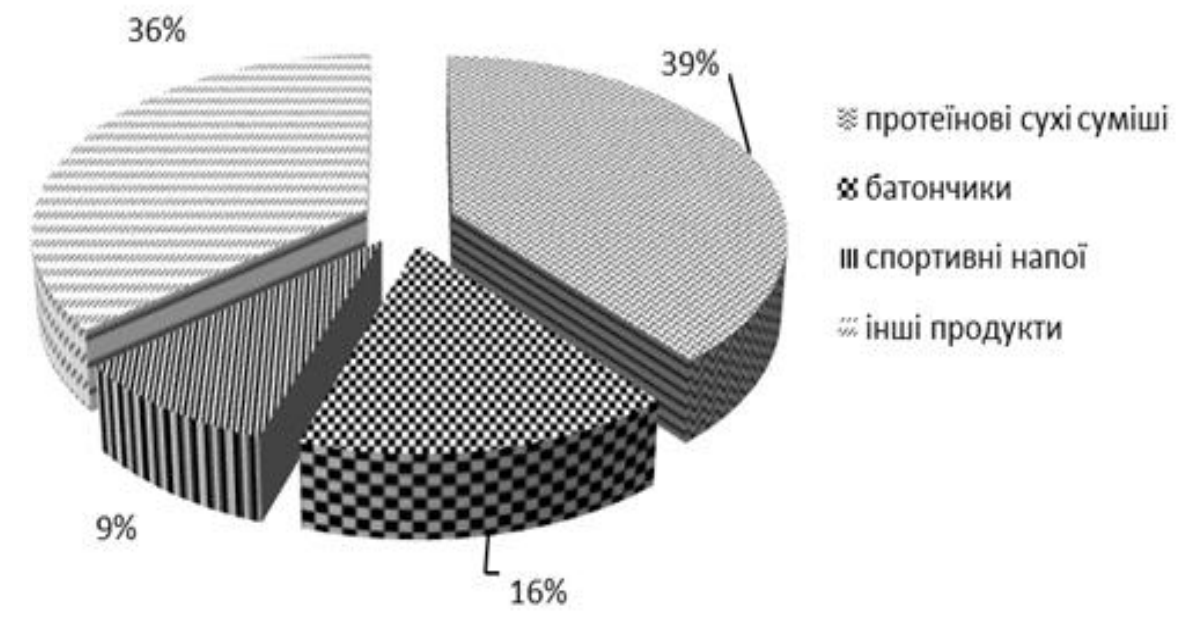

Рис. 1. Структура світового ринку спортивного харчування за видами продуктів [9]

У зв'язку з різноманіттям асортименту продуктів для спортсменів, для здійснення їх ідентифікації важливо визначитися з термінологічним апаратом щодо їх обігу. У чинній редакції Закону України «Про основні принципи та вимоги до безпечності та якості харчових продуктів» [10] поняття продуктів для спеціального дієтичного призначення вилучено, як і всі вищезазначені вимоги щодо них. А отже, виробництво та обіг спортивного харчування відтепер регулюється на загальних підставах без необхідності підтвердження ïx функціональної ефективності. Важливою проблемою безпечності спортивного харчування залишається те, що жодним чином не передбачений контроль наявності у продуктах заборонених у практиці спорту речовин (гормонів, стероїдів, наркотиків, стимуляторів та ін.), навіть тих, вільний обіг яких в Україні заборонений законодавством. Отже, чинна система державного контролю безпечності та якості харчових продуктів для 
спортсменів в Україні робить можливим потрапляння на вітчизняний ринок не лише продукції низької якості, а й небезпечної для здоров’я споживачів.

В країнах СС ефективно діють не тільки загальні нормативні і правові акти, а й обширний перелік специфічних вимог i норм, метою яких $\epsilon$ забезпечення безпечності та якості харчових продуктів та їх ідентифікації.

У країнах СС спортивне харчування регулюється Регламентом ЄС №609/2013 від 12 червня 2013 р. «Про харчування для немовлят та малих дітей, харчування для особливих медичних потреб та повне дієтичне харчування для контролю ваги» [11]. Цим законодавчим актом анулювалася концепція «продуктів харчування для особливих дієтичних потреб». Регламент поширюється лише на 4 групи товарів: молочні суміші для немовлят та подальшого годування; продукти 3 перероблених круп та харчування для немовлят; харчування для особливих медичних потреб та повне дієтичне харчування для контролю ваги. Такі зміни, з одного боку, можуть призвести до негативних наслідків. По-перше, загальне регулювання харчових продуктів не гарантуватиме споживачу з особливими дієтичними потребами надання достатньої кількості інформації. Позначення на маркуванні лише 6 основних нутрієнтів (жирів, насичених жирів, вуглеводів, цукрів, білків та солі) для спортсменів та їх дієтологів однозначно недостатньо. Це унеможливлює правильний розрахунок кількості та частоти споживання продуктів для забезпечення потреб організму. По-друге, виробникам традиційних харчових продуктів немає необхідності у тісній співпраці зі спеціалістами у галузі охорони здоров’я, як і необхідності проводити клінічні дослідження. По-третє, виробники не зможуть робити додаткові заяви щодо призначення своєї продукції на маркуванні та в рекламі, що зараз активно використовується для комунікації зі споживачами. 3 іншого боку, зважаючи на багатоманітність продуктів, що використовується різними групами населення (від спортсменів та бодібілдерів до відвідувачів фітнесцентрів), на даному етапі вже важко ідентифікувати традиційні харчові продукти та продукти для задоволення потреб певних категорій споживачів, користуючись визначенням, наведеним у Директиві. Таким чином, практично однакові продукти можуть одночасно позиціонуватися і як дієтичні, i як звичайні. До того ж навряд чи продукти для спеціального харчування спортсменів можна віднести до групи високого ризику.

Показовим є той факт, що навіть серед виробників немає єдиної думки щодо питання регулювання виробництва та обігу спортивного харчування. Так, асоціація «Спеціальне харчування. Європа» (SNE), яка представляє 
інтереси виробників продуктів для спеціального дієтичного харчування, серед яких «Danone-Nutricia», «Abbott Labs» та «Nestle», наполягає на необхідності введення спортивного харчування у сферу дії Регламенту ЄС № 609/2013. Водночас, Європейський альянс фахівців спортивного харчування (ESSNA), членами якого $\epsilon$, зокрема, «Cytosport», «Dymatize», «GNC», «Glanbia», «NBTY» та «Weider», підтримує регулювання цієї групи продуктів на загальних підставах [12].

Таким чином, чинна законодавчо-нормативна база щодо виробництва та обігу харчових продуктів для спортсменів не визначає чіткої регламентації їх ідентифікації тому важливим вбачається розробка та впровадження дієвого механізму контролю достовірності тверджень виробників щодо особливих властивостей харчових продуктів, що базуватиметься на науковому підході та 3 використанням новітніх методів ідентифікації. Нагальною необхідністю $є$ забезпечення прозорості процедури оцінки ефективності продуктів шляхом встановлення узагальнених i доступних широкому загалу критеріїв та методик. Лише після встановлення чітких вимог щодо безпечності та якості, а також регулювання виробництва та обігу спортивного харчування можна буде здійснювати за загальними принципами і вимогами щодо харчових продуктів.

Для проведення ідентифікаційної експертизи харчових продуктів для спортсменів важливим етапом є розробка критеріїв та засобів ідентифікації.

Для цілей ідентифікації харчових продуктів для спортсменів придатні органолептичні та фізико-хімічні показники, що характеризують споживні властивості самого товару. Мікробіологічні показники належать до показників безпечності, що залежать від впливу зовнішніх факторів і тому не можуть вважатися критеріями ідентифікації.

В роботі представлено розроблені критерії ідентифікації на прикладі батончиків для спортсменів. Основними критеріями ідентифікації даної групи продуктів $\epsilon$ маркування, смак, запах, зовнішній вигляд, форма, цукеркова маса, маса нетто, масова частка вологи і масова частка розчинних вуглеводів, що дозволяють присвоїти певний код батончикам для спортсменів згідно з УКТЗЕД.

Але враховуючи багатокомпонентність складу батончиків для спортсменів, до складу яких входять білок, вуглеводи, жири різного походження, вітаміни, мінеральні елементи, інші біологічно-активні речовини, нами запропоновано доповнити критерії наступними показниками:

- походження білкової складової;

- походження жирової складової; 
- кількісний та якісний склад вітамінів, мінеральних елементів та інших біологічно-активних речовин (табл. 1).

Оскільки батончики для спортсменів є продуктами заданої харчової та енергетичної цінності, до їх складу входять вітаміни, мінеральні речовини та інші біологічно-активні речовини.

Таблиця 1

Критерії ідентифікації батончиків для спортсменів

\begin{tabular}{|c|c|c|}
\hline Мета ідентифікації & Критерій ідентифікації & Результати ідентифікації \\
\hline $\begin{array}{l}\text { Ідентифікація найменування } \\
\text { товару }\end{array}$ & Маркування & $\begin{array}{c}\text { Визначення складових } \\
\text { компонентів продукту, а } \\
\text { також призначення } \\
\end{array}$ \\
\hline $\begin{array}{l}\text { Ідентифікація за } \\
\text { рецептурним складом та } \\
\text { особливостями технології }\end{array}$ & $\begin{array}{c}\text { Смак, запах, зовнішній } \\
\text { вигляд, форма, цукеркова } \\
\text { маса }\end{array}$ & $\begin{array}{c}\text { Визначення } \\
\text { класифікаційної групи за } \\
\text { рецептурним складом та } \\
\text { особливістю } \\
\text { використаної технології }\end{array}$ \\
\hline $\begin{array}{l}\text { Групова ідентифікація згідно } \\
\text { з УКТЗЕД }\end{array}$ & $\begin{array}{c}\text { Маса нетто, наявність } \\
\text { первинної упаковки та } \\
\text { начинки }\end{array}$ & $\begin{array}{c}\text { Визначення коду, згідно з } \\
\text { УКТЗЕД }\end{array}$ \\
\hline $\begin{array}{l}\text { Ідентифікація білкової та } \\
\text { жирової складових }\end{array}$ & $\begin{array}{c}\text { Кількісний та якісний } \\
\text { склад білка, кількісний та } \\
\text { якісний склад жирів } \\
\end{array}$ & $\begin{array}{c}\text { Визначення виду білку та } \\
\text { жиру (підтвердження } \\
\text { походження) } \\
\end{array}$ \\
\hline $\begin{array}{l}\text { Ідентифікація вмісту } \\
\text { вітамінів та мінеральних } \\
\text { елементів, інших біологічно- } \\
\text { активних речовин }\end{array}$ & $\begin{array}{c}\text { Кількісний та якісний } \\
\text { склад вітамінів, } \\
\text { мінеральних елементів, } \\
\text { інших біологічно-активних } \\
\text { речовин }\end{array}$ & $\begin{array}{c}\text { Визначення вмісту } \\
\text { біологічно-активних } \\
\text { речовин }\end{array}$ \\
\hline
\end{tabular}

Важливим при цьому проведення якісної ідентифікації (визначення їх походження (природне чи синтетичне)) та кількісного вмісту у продукті для забезпечення необхідного фізіологічного ефекту на організм людини.

До засобів ідентифікації товарів відносять нормативні документи (стандарти, технічні умови, гігієнічні вимоги, регламенти, директиви тощо), які регламентують показники якості та можуть бути використані для цілей ідентифікації, а також технічні документи, у тому числі товаросупровідні (накладні, посвідчення якості, маркування, паковання та ін.).

Доцільним вбачається включення розроблених критеріїв ідентифікації до нормативного документа, оскільки, саме це дасть можливість ідентифікувати сировину з якої виготовлені батончики для спортсменів та їх приналежність до класифікаційної групи згідно з УКТЗЕД.

Висновки та перспективи подальших досліджень. Запропоновано підходи до ідентифікації харчових продуктів для спортсменів. Проаналізовано 
законодавчо-нормативне забезпечення ідентикації даної групи продуктів. Розроблено критерії ідентифікації батончиків для спортсменів. Подальшого дослідження потребує розробка засобів ідентифікації продуктів для спортсменів із використанням експрес-методик та проведення стандартизації запропонованих критеріїв ідентифікації.

\section{Список використаних джерел}

1. Штепа О.П. Гігієнічні вимоги до харчування та питного режиму спортсменів єдиноборців (боксерів, борців): автореф. ... дис. канд. мед. наук: 14.02 .01 / О.П. Штепа. Донецьк, 2010. 20 c.

2. Николаева М.А., Положишникова М.А. Идентификация и обнаружение фальсификации продовольственных товаров: учебное пособие. М.: ИД«ФОРУМ»: ИНФРАM, 2009. $464 \mathrm{c}$.

3. Притульська Н.В. Ідентифікація продовольчих товарів: теорія i практика: монографія. К.: Київ. нац. торг.-екон. ун-т, 2007. 193 с.

4. Дубініна А.А. Методи визначення фальсифікації товарів. Х.: Центр навчальної літератури, 2017. 272 с.

5. Shahrooz Rahmatia Nurhidayatullaili Muhd JulkapliaWageeh A.YehyeaWan JefreyBasirunab Identification of meat origin in food products. Food Control. 2016. Volume 68, October. P. 379-390

6. Maria Teresa Bottero, Alessandra Dalmasso. Animal species identification in food products: Evolution of biomolecular methods. The Veterinary Journal. 2011. Volume 190, Issue 1, October. P. 34-38

7. Datamonitor. Exercise and Sports Nutrition: Consumer Trends and Product Opportunities [Electronic resourse]. Available: <from:http://about.datamonitor. com/media/archives/5546>.

8. Sports Nutrition growing in the Baltic States. GMID: глобальна база даних інформації про ринки (Euromonitor International) від 22.08.2019 [Електронний ресурс]. Режим доступу: http://blog.euromonitor.com/2016/08/sports-nutrition-growing-balticstates.html.

9. Trends and Developments in Sports Nutrition. GMID: глобальна база даних інформації про ринки (Euromonitor International) [Електронний ресурс]. Режим доступу: http://www.euromonitor.com/sports-nutrition.

10. Про основні принципи та вимоги до безпечності та якості харчових продуктів: Закон України від 20.09.2015 № 771/97-ВР. [Електронний ресурс]. Режим доступу: http://zakon3.rada.gov.ua/laws/show/771.

11. Regulation No 609/2013 of the European Parliament and of the Council of 12 June 2013 on food intended for infants and young children, food for special medical purposes, and total diet replacement for weight control [Electronic resource]. Way of access: https://www.fsai.ie/uploadedFiles/Reg609_2013.pdf 
12. ESSNA: Specific sports food laws wood 'hurt rather than help' in Europe. [Електронний ресурс].- Режим доступу: http://www.nutraingredients.com/RegulationPolicy/ESSNA-Specific-sports-food-laws-would-hurt-rather-than-help-in-Europe.

\section{References}

1. Shtepa O.P. (2010). Hihiienichni vymohy do kharchuvannia ta pytnoho rezhymu sportsmeniv- yedynobortsiv (bokseriv, bortsiv) [Hygienic requirements for the nutrition and drinking regime of martial sportsmen (boxers, wrestlers)]. Abstract of PhD thesis. Donetsk [in Ukrainian].

2. Nykolaeva M.A., Polozhyshnykova M.A. (2009). Identifikatsyya i obnaruzheniye falsifikatsyi prodovolstvennykh tovarov [Identification and detection of falsifications in food products]. Moscow.: YD "FORUM": YNFRA-M [in Russian].

3. Prytulska N.V. (2007). Identyfikatsiia prodovolchykh tovariv: teoriia i praktyka [Identification of food products: theory and practice]. Kyiv: Kyiv National University of Trade and Economics [in Ukrainian].

4. Dubinina A.A. (2017). Metody vyznachennia falsyfikatsii tovariv [Methods for identification of commodity falsifications]. Kharkiv: Center of Education Literature [in Ukrainian].

5. Shahrooz Rahmati, Nurhidayatullaili Muhd Julkapli, Wageeh A.Yehye, Wan Jefrey Basirun (2016). Identification of meat origin in food products. Food Control, 68, 379-390.

6. Maria Teresa Bottero, Alessandra Dalmasso (2011). Animal species identification in food products: Evolution of biomolecular methods. The Veterinary Journal, vol. 190, issue 1, $34-38$.

7. Datamonitor. Exercise and Sports Nutrition: Consumer Trends and Product Opportunities. Retrieved from http://about.datamonitor. com/media/archives/5546>.

8. Sports Nutrition growing in the Baltic States (Euromonitor International) from 22.08.2019. Retrieved from http://blog.euromonitor.com/2016/08/sports-nutrition-growing-balticstates.html.

9. Trends and Developments in Sports Nutrition (Euromonitor International). Retrieved from http://www.euromonitor.com/sports-nutrition.

10. Pro osnovni pryntsypy ta vymohy do bezpechnosti ta yakosti kharchovykh produktiv: Zakon Ukrainy vid 20.09.2015 No 771/97-VR [Main principles and requirements for safety and quality of food products: the Law of Ukraine from 20.09.2015 No 771/97-VR]. Retrieved from http://zakon3.rada.gov.ua/laws/show/771. [in Ukrainian].

11. Regulation No 609/2013 of the European Parliament and of the Council of 12 June 2013 on food intended for infants and young children, food for special medical purposes, and total diet $\begin{array}{lllll}\text { replacement for } & \text { weight } & \text { control. } & \text { Retrieved }\end{array}$ https://www.fsai.ie/uploadedFiles/Reg609_2013.pdf

12. ESSNA: Specific sports food laws wood 'hurt rather than help' in Europe. [Електронний pecypc]. Retrieved from http://www.nutraingredients.com/RegulationPolicy/ESSNA-Specific-sports-food-laws-would-hurt-rather-than-help-in-Europe. 
Цель. Разработка научно-практических подходов к идентификачии пищевых продуктов для спортсменов.

Методика. В основу методологической базы исследования положены методы научного познания, системного подхода и обобщения, законодательно-нормативные акты Украины и ЕС, научные работы.

Результаты. Постоянный рост на отечественном рынке количества фальсифицированных пищевых продуктов для спортсменов, их незаконное перемещение через таможенную гранииу и другие факторы обусловливают необходимость проведения работ по идентификации. Нормативная база по производству и обороту пищевых продуктов для спортсменов не определяет четкой регламентачии проведения прочедуры их идентификации, поэтому важным представляется разработка и внедрение действенного механизма контроля достоверности утверждений производителей по особых свойств пищевых продуктов, основанную на научном подходе и с использованием новых методов идентификации. Установлено, что для проведения идентификационной экспертизы пищевых продуктов для спортсменов важным этапом является разработка критериев и средств идентификации.

В работе разработаны критерии идентификации пищевых продуктов для спортсменов на примере батончиков. К важных критериев идентификации данной группь продуктов относятся: маркировка, вкус, запах, внешний вид, форма, конфетная масса, масса нетто, массовая доля влаги и массовая доля углеводов, происхождения белковой и жировой составляющих; количественный и качественный состав биологически активных веществ.По результатам идентификаџии по органолептическим и физико-химическим показателям исследуемые образиьл батончиков для спортсменов соответствуют требованиям действующего нормативного документа. Однако, использование только стандартизированных показателей качества с целью идентификации не обеспечивает объективное проведение процедуры идентификачии продуктов. Целесообразным представляется включение разработанных критериев идентификации в нормативный документ, поскольку именно это позволит эфективно провести экспертизу товара.

Научная новизна. Проанализированы подходы к идентификации пищевых продуктов для спортсменов. Разработаны критерии идентификации батончиков для спортсменов и проведено их идентификаџионную экспертизу.

Практическая ценность. Предложено стандартизировать разработаннье критерии идентификации путем их включения в нормативную документацию для повышения эффективности проведения процедуры идентификации контролирующими органами, торговыми организачиями, потребителями.

Ключевые слова: продукты питания для спортсменов, идентификачия, критерий идентификации, средство идентификации, рынок, регламент.

Purpose. To develop theoretical and practical approaches to identification of food products for sportsmen.

Methodology. The methodological framework of the research is based on the methods of scientific inquiry, the system approach and generalization, legal and regulatory acts of Ukraine and EU, scientific works. 
Findings. The continual growth in the number of falsified food products for sportsmen on the domestic market, their illegal transfer across the custom border and other factors cause the need for efforts aimed at their identification. The regulatory framework on manufacturing and distribution of food products for sportsmen does not contain a clear regulation of their identification procedure, which raises the importance of development and implementation of the effective mechanism for control of the reliability of manufacturers' statements about specific properties of food products, based on the scientific approach and involving innovative methods of identification. It is argued that an important phase in the identification expertise of food products for sportsmen is elaborating criteria and means of identification.

Criteria for identification of food products for sportsmen are elaborated by case of candy bar. The important criteria for identification of this product group include: marking, taste, smell, appearance, form, sugar mass, net mass, mass percentage of moisture and mass percentage of carbohydrates, origin of protein component; origin of fats; quantitative and qualitative composition of biologically active substances.

The results of identification by organoleptic and physical-chemical indicators demonstrate that the tested samples of candy bars for sportsmen comply with the requirements of the current regulatory document. However, if testing for identification purpose is confined to the standardized quality indicators, it will not ensure the soundness of the product identification procedure. Inclusion of the elaborated identification criteria in the regulatory document seems appropriate, because it will enable for the commodity expertise.

Originality. The approaches to identification of food products for sportsmen are analyzed. Identification criteria for candy bars for sportsmen are elaborated, and their identification expertise is performed.

The practical value. It is proposed to standardize the elaborated identification criteria through their inclusion in the regulatory documents for enhancing the effectiveness of the identification procedure performed by supervisory authorities, trade organizations or consumers.

Keywords: food products for sportsmen, identification, identification criteria, means of identification, market, regulations.

Стаття рекомендована до друку доктором технічних наук, професором, завідувачкою кафедри товарознавства, управління безпечністю та якістю Київського національного торговельно-економічного університету Белінською С.О. Стаття надійшла в редакиію 20.11.2019 р. 